\begin{tabular}{|c|c|c|c|c|}
\hline JURNAL & \multirow{2}{*}{ NOLUME 2 } & \multirow{2}{*}{ NOMOR 2 } & HALAMAN 74-85 & $\begin{array}{l}\text { ISSN 2655-8823 }(p) \\
\text { ISSN 2656-1786 }(e)\end{array}$ \\
KOLABORASI RESOLUSI KONFLIK & VOLA \\
\hline
\end{tabular}

\title{
KONFLIK GERAKAN MASYARAKAT SIPIL DAN PEMERINTAH DALAM PROSES PENYUSUNAN RANCANGAN UNDANG-UNDANG OMNIBUS LAW
}

\author{
Muhammad Fakhrur Razy \\ Pascasarjana Magister Sosiologi FISIP Unpad \\ E-mail: muhammadfakhrurrazy@gmail.com \\ Muhammad Fedryansyah \\ Departemen Kesejahteraan Sosial FISIP Unpad \\ E-mail: m.fedryansyah@unpad.ac.id
}

\begin{abstract}
ABSTRAK
Konflik Gerakan Masyarakat Sipil dan Pemerintah masih sangat sering terjadi di Indonesia apalagi bersinggungan dengan kebijakan atupun proses peyusunan kebijakan. Salah satunya adalah proses pnyusunan Rancangan undang-undang Omnibus Law yang menuai kontroversi ditengah kehidupan masyarakat akibat dari kurangnya komunikasi politik yang dibangun oleh pemerintah, adanya politik relation yang melibatkan segelintir orang yang memiliki kepentingan dan hubungan yang deekat dengan pemerintahan serta kurangnya partisipasi politik dalam hal ini masyarakat kelas bawah yang secara langsung merasakan dampak dari RUU tersebut jika di sahkan. Artikel ini bertujuan untuk menjelaskan siapa saja yang terlibat dalam konflik gerakan masyarakat sipil dan pemerintah dalam proses penyusunan Rancangan Undang-Undang Omnibus Law serta apa yang menjadi penyebab terjadinya konflik tersebut. kajian konflik proses penyusunan omnibus law ini melakukan analisis menggunakan pemberitaan di media sosial serta kajian literatur lainnya.
\end{abstract}

Kata Kunci: Konflik, Omnibus Law, Undang-Undang, Masyarakat

\section{PENDAHULUAN}

Indonesia menjadi salah satu negara yang memiliki prodak hukum yang begitu banyak prodak-prodak tersebut menjadi acuan untuk pemerintah dalam menjalankan sistem pemerintahannya. Sehingga tidak sedikit kita melihat kebijakan-kebijakan yang di keluarkan oleh pemerintah, baik Undang-undang yang di bahas melalui gedung parlemen, peraturan presiden (PERPRES), Peraturan Menteri (PERMEN), Peraturan Pemerintah (PP), Rancangan Kitab Undang-Undang Hukum Pidana (RKUHP) dan yang saat ini sedang ramai di perbincangkan yaitu Omnibus Law atau yang di kenal dengan Undang-Undang sapu jagad.

Dalam proses penyusunan perundangundangan di Indonesia tidak sedikit menuai konflik dalam kehidupan masyarakat. Pada September 2019 gerakan penolakan Rancanag Kitab UndangUndang Hukum Pidana (RKUHP) bergejolak di seluruh daerah di Indonesia.
Setelah demo mahasiswa mengepung Gedung DPR RI Jakarta, mahasiswa di berbagai daerah kembali menggelar aksi, seperti di Kalimantan Barat, Sulawesi Tengah, Sumatra Barat dan wilayah lainnya, Rabu, 25 September 2019. Demonstrasi tersebut adalah salah satu bentuk kritikan terhadap pemerintahan Indonesia yang selalu terkesan tergesagesa dalam proses pembuatan dan pengesahan berbagai macam kebijakan di Indonesia termaksud RKUHP yang digodok selama dua hari, sehingga isi kandungan RKUHP dan berbagai produk hukum lainnya memiliki banyak pasal kontroversi. (Tirto.id, 2020 April 24).

Setelah RKUHP, Omnibus law sebagai produk hukum yang baru di periode kedua Presiden Jokowidodo juga mengalami penolakan. Omnibus law yang menampung kurang lebih 76 Undangundang dan 1.200 pasal ini bertujuan untuk menyatukan pelbagai macam undangundang menjadikan satu agar tidak adanya 


\begin{tabular}{|c|c|c|c|c|}
\hline JURNAL & \multirow{2}{*}{ VOLUME 2 } & \multirow{2}{*}{ NOMOR 2 } & HALAMAN 74-85 & $\begin{array}{l}\text { ISSN 2655-8823 }(p) \\
\text { ISSN 2656-1786 }(e)\end{array}$ \\
\hline
\end{tabular}

tumpang tindih aturan, serta bertujuan untuk mempermuda investasi masuk ke Indonesia agar tidak berbelit-belit. Akan tetapi produk hukum yang baru saja di perkenalkan tersebut di nilai sangat tergesa-gesa oleh kelompok masyarakat sipil serta tidak melibatkan berbagai macam stakeholder yang memiliki kaitan langsung dengan produk RUU omnibus law tersebut seperti serikat buruh, aktivis lingkungan dan aktivis HAM serta kelompok masyarakat sipil lainnya.

Produk rancanagan undang-undang omnibus law ini di nilai sangat tergesagesa untuk disahkan. Sebab Presiden Jokowidodo menargetkan Rancangan Undang-Undang omnibus law bisa selesai dalam waktu 100 hari saja. Padahal Omnibus Law sendiri digagas dengan harapan memberikan kelapangan dan kemudahan dalam menanamkan investasi bisnis di Indonesia. Hanya saja keinginan kerja cepat yang dicanangkan oleh Presiden Jokowi itu justru terkesan penuh ketergesa-gesaan. Ingin cepat rampung tetapi banyak aspek yang tidak terakomodir termaksud berbagai stakeholder yang terkait dengan RUU omnibus law ini sehingga memunculkan penolakan. (Kompasiana.com, 2020 April 25).

Penolakan gerakan masyarakat sipil terhadap produk rancangan omnibus law ini memiliki berbagai macam alasan, selain poin-poin yang terkandung dalam omnibus law di nilai banyak merugikan kaum pekerja, produk omnibus law ini dalam penyusunannya juga sangat tidak partisipatif dengan tidak melibatkan kaum pekerja sebagai salah satu sektor yang nantinya akan merasakan langsung dampak dari omnibus law melalui rancangan undang-undang cipta kerja (CIPTAKER). Konfederasi Serikat Pekerja Seluruh Indonesia (KSPSI) mengatakan bahwa buruh tidak dilibatkan dalam penyusunan omnibus law, Presiden KSPSI juga memberikan saran kepada pemerinta agar pemerintah berkomunikasi dengan buruh sebelum merumuskan aturan omnibus law. (Kompas.com, 2020 April 23).

Bukan hanya serikat pekerja yang melakukan penolakan dan memberikan komentar terkait rancangan omnibus law. Pusat Studi Hukum Konstitusi juga menjelaskan bahwa banyak materi dalam RUU itu yang bermasalah. Sehingga kami menyatakan perlunya DPR mengembalikan RUU Omnibus Law kepada presiden dan mengubah ketentuan yang kontroversial serta memuat beragam aspirasi yang telah dilontarkan oleh masyarakat, kata Direktur PSHK FH UII, Allan Fatchan Gani Wardhana. (Tribunjogja.com, 2020 April 24).

Selain PSHK FH UII terdapat dua lembaga/komisi negara seperti Ombudsman RI dan Komnas HAM RI yang mengaku sampai pada tanggal 31 Januari masih sulit untuk mendapatkan draft omnibus law. Walaupun pihak obudsaman pada prosesnya telah melayangkan surat pada desember 2019 untuk meminta draft RUU Omnibus Law yang dimaksud kepada Menteri Koordinator Bidang Perekonomian sayangnya, niat baik itu tidak mendapat respon positif sesuai yang diharapkan Pada intinya Kemenko Perekonomian menolak memaparkan draft RUU itu dengan alasan draft belum disetujui Presiden dan belum ada arahan dari Menteri. (hukumonline.com, 2020 April 23).

Selain itu Fraksi Rakyat Indonesia (FRI) menilai bahwa dalam proses penyusunan omnibus law adalah keseluruhan proses yang sangat tertutup, tidak demokratis, dan hanya melibatkan pengusaha. Selain itu, substansi RUU Cilaka Indonesia menyerupai watak pemerintah kolonial Hindia Belanda. FRI juga memaparkan 12 alasan menolak Omnibus Law RUU Cilaka. Seperti penyusunan RUU Cilaka cacat prosedur karena dilakukan secara tertutup, satgas omnibus law bersifat elitis, sentralisme kewenangan yaitu kebijakan ditarik ke pemerintah pusat yang mencederai semangat reformasi, celah korupsi melebar 


\begin{tabular}{|c|c|c|c|c|}
\hline JURNAL & \multirow{2}{*}{ VOLUME 2 } & \multirow{2}{*}{ NOMOR 2 } & \multirow{2}{*}{ HALAMAN 74-85 } & $\begin{array}{l}\text { ISSN 2655-8823 }(p) \\
\text { ISSN 2656-1786 }(e)\end{array}$ \\
\hline
\end{tabular}

akibat mekanisme pengawasan yang dipersempit, dan penghilangan hak gugat oleh rakyat. (Detik.com, 2020 April 24).

Fraksi Rakyat Indonesia (FRI) terdiri dari 40 organisasi non pemerintahan seperti Konfederasi Kongres Aliansi Serikat Buruh Indonesia (KASBI), Konfederasi Persatuan Buruh Indonesia (KPBI), Sentra Gerakan Buruh Nasional (SGBN), Konfederasi Serikat Nasional (KSN), Pergerakan Pelaut Indonesia, Serikat Pekerja Media dan Industri Kreatif untuk Demokrasi (SINDIKASI), Federasi Pekerja Pelabuhan Indonesia, Konsorsium Pembaharuan Agraria (KPA), Wahana Lingkungan Hidup Indonesia (WALHI), Jaringan Advokasi Tambang (JATAM), Yayasan Lembaga Bantuan Hukum Indonesia (YLBHI), Aliansi Masyarakat Adat (AMAN), Liga Mahasiswa Nasional Untuk Demokrasi Dewan Nasional (LMND-DN) serta beberapa organisasi lainnya.

Dari data di atas telah menjelaskan bahwa sistem pemerintahan Indonesia dalam proses pembuatan berbagai produk hukum di nilai sangat tergesa-gesa dalam penetapannya dan tidak partisipatif dalam mengambil kebijakan seperti melibatkan organisasi masyrakat aktivis buruh, aktivis lingkungan, aktivis ham dan aktivis mahasiwa, sehingga prodak hukum yang telah di buat terkesan tertutup dan tidak demokratis. Berdasarkan latar belakang tersebut, penulis ingin mengkaji konflik yang terjadi antara gerakan masyarakat sipil dan pemeintah dalam proses penysunan rancangan undang-undang omnibus law. Siapa saja Pihak-pihak yang terlibat dan berkonflik dalam proses penyusunan Rancangan Undang-Undang omnibus law serta apa yang menjadi penyebab sehingga terjadinya konflik gerakan masyarakat sipil dan pemerintah dalam proses penyusunan Rancangan Undang-Undang Omnibus Law.

\section{METODE PENELITIAN}

Dalam artikel konflik gerakan masyarakat sipil dan pemerintah dalam proses penyusunan rancangan undangundang omnibus law ini, digunakan metode studi literatur, jurnal, buku, serta konten analisis dari media massa yang dikaitkan dengan teknik analisa situasi konflik dari kacamata sosiolog Simon Fisher dkk.

\section{HASIL DAN PEMBAHASAN}

Kebijakan yang di keluarkan oleh pemerintah maupun hasil dari pembaharuan kembali perundangundangan menjadi salaha satu rujukan untuk mengatur kehidupan sosial masyarakat agar tetap mendapatkan social equilibrium atau keseimbangan sosial. Sehingga dari kehidupan sosial yang seimbang menciptakan tatanan kehidupan sosial masyarakat yang adil dan sejahtera, sehingga itulah pentingnya berbagai macam produk kebijakan yang di ciptakan oleh pemerintah agar masyarakat mendapatkan kepastian hukum. (Hidayat \& Arifin, 2019).

Akan tetapi tidak sedikit dari pelbagai macam produk hukum yang di keluarkan oleh pemerintah menuai kontroversi di kalangan masyarakat sipil, baik isi dari peraturan tersebut maupun proses dalam penyusunan perundang-undangan. Kontroversi kebijakan maupun proses pembuatan tersebut anatara pemerintah dan masyarakat sipil itulaha yang di sebut dengan konflik vertikal atau konflik struktural, sehingga konflik menjadi hal yang tidak bisa kita hindari dalam kehidupan sosial masyarakat, bahkan di manapun dan kapanpun konflik akan tetap ada di dalam kehidupan sosial masyarakat baik dalam struktur sosial yang paling kecil sampai pada struktur sosial tertinggi sebab manusia adalah makhluk yang tidak lepas dari konflik. Seperti yang di jelaskan oleh (Novri Susan 2014) bahwa manusia adalah mahluk konfliktis (homo conflictus).

Konflik adalah fenomena yang tidak bisa terhindarkan dari kehidupan manusia. Sebab konflik akan selalu terjadi baik dalam keluarga sebagai struktur yang 


\begin{tabular}{|c|c|c|c|c|}
\hline JURNAL & \multirow{2}{*}{ VOLUME 2 } & \multirow{2}{*}{ NOMOR 2 } & HALAMAN 74-85 & $\begin{array}{l}\text { ISSN 2655-8823 }(p) \\
\text { ISSN 2656-1786 }(e)\end{array}$ \\
\hline
\end{tabular}

paling kecil maupun negara sebaga struktur terbesar, konflik bisa saja terjadi antara individu dengan individu, kelompok dan individu atau kelompok dengan kelompok.

Dalam penjelasannya Hebermas (dalam Zuldin, 2019) mengemukakan bahwa konflik adalah suatu yang in heren dalam kehidupan masyarakat. Artinya konflik menjadi hal yang tetap dan tidak bisa di hindari dalam kehidupan sosial masyarakat, sebab konflik memiliki sifat parmanen dalam kehidupan sosialnya.

Lebih lanjut (Simon Fisher, Dkk. 2001) dalam bukunya menjelaskan konflik adalah hubungan antara dua pihak atau lebih (individu atau kelompok) yang memiliki sasaran-sasaran yang tidak sejalan. Dari tingkat mikro konflikpun terjadi antar pribadi hingga antar kelompok.

Gejolak perlawanan gerakan masayarakat sipil terhadap rancangan undang-undang omnibus law menjadi hal yang menarik untuk di kaji dalam prespektif konflik Simon Fisher, dalam bukunya juga menjelaskan bahwa konflik sosial akan muncul apabilah tidak adanya keseimbangan dalam struktur sosial masyarakat termaksud proses dalam menentukan kebijakan publik, sehingga bisa menghasilkan kekuasaan yang tidak seimbang dan akan menghasilkan kesenjangan sosial.

Dalam artikel ini, penulis menganalisis konflik gerakan masyarakat sipil dan pemerintah dalam proses penyusunan rancangan undang-undang omnibus law menggunakan pemetaan konflik dan analogi pilar Simon Fisher.

\section{Pihak-Pihak yang Terlibat dan Berkonflik dalam Proses Penyusunan RUU Omnibus Law}

Dalam poin ini penulis akan melakukan pemetaan siapa saja yang terlibat dalam proses penyusunan rancangan undang-undang omnibus law dan siapa saja kelompok yang berkonflik. Sehingga pembaca bisa mengetahui peta konflik yang terjadi. Sesuai dengan pemetaan konflik yang di kenalkan oleh Simon Fisher. Berikut pihak-pihak yang terlibat dalam proses penyusunan rancangan undang-undang omnibus law dan pihak yang melakukan kritik terhadap proses pembuatan rancangan undangundang omnibus law:

1. Lembaga Eksekutif

Lembaga eksekutif sebagai lembaga pemerintahan yang memiliki berbagai banyak wewenang salah satunya seperti yang di atur dalam undang-undang dasar 1945 pasal 5 ayat 1 bahwa Presiden berhak mengajukan rancangan undang-undang kepada Dewan Perwakilan Rakyat. Dalam kasus rancangan undang-undang omnibus law lembaga eksekutif dalam hal ini Menteri Koordinator Bidang Perekonomian mengeluarkan keputusan Nomor 378 Tahun 2019 tentang Satuan Tugas Bersama Pemerintah dan Kadin untuk Konsultasi Publik Omnibus Law.

Setelah pembentukan satgas, Menko Perekonomian Airlangga Hartarto, yang didampingi Menteri Ketenagakerjaan Ida Fauziyah, Menteri Keuangan Sri Mulyani, Menteri LHK Siti Nurbaya, Menteri ATR Sofjan Djalil, hingga Menteri Hukum dan HAM Yasonna Laoly mengantarkan surat presiden dan draf rancangan undang-undang omnibus law. (Kumparan.com, 2020 April 25).

2. Satuan Tugas (Satgas)

Dalam proses penyusunan rancangan undang-undang omnibus law pemerintah membentuk satuan tugas bersama pemerintah dan kadin untuk konsultasi publik omnibus law. Dalam satgas tersebut di ketuai oleh Rosan Roesali yang juga selaku ketua umum Kamar Dagang dan Industri (KADIN), selain pemerintah dan 


\begin{tabular}{|c|c|c|c|c|}
\hline JURNAL & \multirow{2}{*}{ VOLUME 2 } & NOMOR 2 & HALAMAN 74-85 & $\begin{array}{l}\text { ISSN 2655-8823 }(p) \\
\text { ISSN 2656-1786 }(e)\end{array}$ \\
\hline
\end{tabular}

akademisi satgas omnibus law tersebut di dominasi oleh pihak pengusaha yang terdiri dari 16 orang termaksud dalam pengurus pusat dan daerah Kadin.

Selain Kadin, terdapat beberapa ketua asosiasi bisnis yang tergabung dalam satgas tersebut seperti Ade Sudrajat (Asosiasi Pertekstilan Indonesia), Sanny Iskandar (Himpunan Kawasan Industri), Eddy Widjanarko (Asosiasi Persepatuan Indonesia), Hariyadi Sukamdani (Asosiasi Perhimpunan Hotel Indonesia), Aryan Warga Dalam (Asosiasi Pulp dan Kertas Indonesia), dan Yukki Nugrahawan Hanafi (Asosiasi Logistik dan Forwarder Indonesia). Selain itu tercatat beberapa anggota satgas juga sebagai pengusaha seperti Joko Supriyono (Gabungan Pengusaha Kelapa Sawit Indonesia), Adhi Lukman (Gabungan Pengusaha Makanan dan Minuman Seluruh Indonesia), Benny Soetrisno (Gabungan Pengusaha Eksportir Indonesia), Roy Nicholas Mande (Asosiasi Pengusaha Ritel Indonesia), Moenardji Soedargo (Gabungan Perusahaan Karet Indonesia), dan Pandu Patra Sjahrir (Asosiasi Pertambangan Batubara Indonesia), Indroyono Soesilo (Asosiasi Pengusaha Hutan Indonesia), Tirto Kusnadi (Gabungan Perusahaan Farmasi Indonesia), Surracti Sasmita (Asosiasi Pengusaha Indonesia), Kamaluddin Hasyim (Gabungan Usaha Penunjang Energi dan Migas), Iskandar Z Hartawi (Gabungan Pelaksana Konstruksi Nasional Indonesia), dan Joseph Pangalila (Gabungan Perusahaan Nasional Rancang bangun Indonesia), Carmelita Hartoto (Indonesian Nasional Shipowner's Association), Putri K Wardhani
(Perhimpunan Perusahaan dan Asosiasi Kosmetika Indonesia), Mardani H Maming (Himpunan Pengusaha Muda Indonesia), dan Totok Lusida (Dewan Pimpinan Pusat Real Estate Indonesia). (Tirto.id, 2020 April 25).

Dari data di atas telah menjelaskan bahwa satuan tugas yang mengawal proses pembentukan rancangan undangundang omnibus law di dominasi oleh pihak pengusaha dari berbagai sektor.

3. Lembaga Legislatif

Lembaga legislatif memiliki tugas sebagai lembaga yang menyusun program legislasi nasional, menyusun dan membahas rancangan undang-undang, membahas ruu yang di sarankan oleh presiden, menetapkan undangundang bersama presiden, menerima RUU yang di ajukan oleh DPD serta Menyetujui atau tidak menyetujui peraturan pemerintah pengganti UU (yang diajukan Presiden) untuk ditetapkan menjadi UU. Selain itu (dpr.go.id, 2020 April 29).

Dari penjelasan di atas maka DPR RI memiliki peran untuk membahas rancangan undangundang omnibus law yang di ajukan oleh lembaga eksekutif pada 12 Februari 2020. Pembahasan tersebut di bahas oleh Badan Legislasi Nasional (BALEG) dalam rapat paripurna membahas Program Legislasi Nasional (PROGLENAS) tahun 2020.

Ketiga lembaga di atas jika merujuk pada grafik pemetaan konflik pada halaman sebelumnya mereka memiliki hubungan yang agak dekat bahkan ada pihak yang beraliansi. Kita melihat bahwa berdasarkan amanat undangundang dasar Eksekutif dan Legislatif memiliki hubungan kerja 


\begin{tabular}{|c|c|c|c|c|}
\hline JURNAL & \multirow{2}{*}{ NOLUME 2 } & \multirow{2}{*}{ HALAMAN 74-85 } & $\begin{array}{l}\text { ISSN 2655-8823 }(p) \\
\text { ISSN 2656-1786 }(e)\end{array}$ \\
\hline KOLABORASI RESOLUSI KONFLIK & VOLUME \\
\hline
\end{tabular}

yang cukup dekat. Sementara Lembaga Eksekutif atau pemerintah membangun satu aliansi bersama pihak akademisi dan pengusaha yang di beri nama satuan tugas bersama pemerintah dan kadin untuk konsultasi publik omnibus law. Selain pihak yang memiliki hubungan yang dekat bahkan sampai pihak yang berkoalisi, ada kelompok yang mendukung agar rancangan undang-undang omnibus law segera di sahkan yaitu pihak Partai Politik dan Pengusaha.

4. Partai Politik dan Pengusaha

Surbakti (dalam Martono, 2014) menjelaskan bahwa partai politik menjadi salah satu alat bagi negara untuk menjadi kontrol politik, selain itu partai politik juga menjadi pemandu dalam menjalankan kepentingan kelompok tertentu. Lebih lanjut Castles (dalam Martono, 2014) juga menjelaskan bahwa partai politik selain memiliki hal positif bagi negara modern yang menganut sistem demokratis juga dapat menjadi kutukan bagi masyarakat jika partai politik di gunakan untuk memobilisasi kepentingan kelaskelas tertentu atau penguasa.

Dari penjelasan di atas sedikit menjelaskan tentang wujud dari partai politik yang memiliki kemungkinan untuk mendorong kepentingan kelas-kelas tertentu. Jika kita merujuk pada topik pembahasan artikel ini melihat proses penyusunan rancangan undang-undang omnibus law yang mendapatkan dukungan dari partai politik dan pengusaha untuk segera di sahkan.

Seperti pernyataan sikap dua partai politik besar di Indonesia yaitu Golkar dan Nasdem melalui pimpinannya menyatakan telah bersepakat untuk mendukung rancangan undang-undang omnibus law untuk segera disahkan. (cnnindonesia.com, 2020 April 29).

Selain partai politik pihak pengusaha juga mendorong dan mendukung agar rancangan undang-undang omnibus law segera di sahkan. Seperti yang dikatakan oleh Wakil Ketua Dewan Pertimbangan Kadin DKI Jakarta Sarman Simanjorang menilai pembahasan Rancangan UndangUndang (RUU) Cipta Kerja tetap harus dilanjutkan. Ia mengklaim kalangan pengusaha tetap mendukung agar RUU Sapu Jagad ini terus dibahas, meski berada dalam masa pandemi virus corona (COVID-19).

Sehingga dari penjelasan di atas partai politik dan Pengusaha menjadi satu kekuatan yang memberikan dukungan kepada pihak legislatif untuk segera membahas dan mengesahkan rancangan undang-undang omnibus law. Jika kita berdasarkan pada grafik pemetaan konflik di atas maka pihak partai politik dan pihak pengusaha menjadi salah satu dukungan eksternal bagi pemerintah untuk segera mengsahkan rancangan undangundang tersebut. Selain pihak yang memberikan dukungan terhadap pemerintah untuk segera mengsahkan rancangan undangundang tersebut ada juga pihak yang melakukan kritik bahkan penolakan terhadap rancangan undang-undang tersebut yaitu Gerakan Masyarakat Sipil.

5. Gerakan Masyarakat Sipil

Gerakan Masyarakat Sipil adalah sebuah gerakan yang di bangun oleh masyarakat atas dasar kesadaran mereka untuk memperjuangkan hak yang mereka miliki. Gerakan tersebut terdiri dari seluruh organisasi non 


\begin{tabular}{|c|c|c|c|c|}
\hline JURNAL & \multirow{2}{*}{ VOLUME 2 } & NOMOR 2 & HALAMAN 74-85 & $\begin{array}{l}\text { ISSN 2655-8823 }(p) \\
\text { ISSN 2656-1786 }(e)\end{array}$ \\
\hline
\end{tabular}

pemerintahan seperti Ngo, Serikat Buruh, Aktivis mahasiswa serta elemen masyarakat lainnya yang menyatukan satu kekuatan untuk mendorong apa yang telah menjadi hak rakyat. Salah satunya adalah Fraksi Rakat Indonesia (FRI) salah satu gerakan masyarakat sipil yang menyatukan 40 organisasi kedalam satu aliansi yang mengkritik hadirnya rancangan undang-undang omnibus law.

Dari saat pertama hadirnya omnibus law telah banyak di kritik oleh gerakan masyarakat sipil. Terakhir gerakan masyarakat sipil melakukan demonstrasi via media sosial pada tanggal 7 April 2020. Seperti yang di jelaskan oleh Ketua Badan Legislasi DPR RI Supratman Andi Agtas bahwa pihaknya beserta sepuluh pimpinan Baleg lainnya mendapatkan kiriman sms atau aplikasi percakapan whatsapp yang berisikan penolakan terhadap rancangan undang-undang omnibus law yang dilakukan oleh sekitar 10 ribu buruh. (cnnindonesia.com, 2020 April 29).

Sehingga dalam hal ini gerakan masyarakat sipil menjadi pihak yang berkonflik baik dengan lembaga eksekutif maupun legislatif seperti yang telah di gambarkan dalam grafik pemetaan konflik.

\section{Penyebab Terjadinya Konflik dalam Proses Penyusunan Rancangan Undang- Undang Omnibus Law}

Setelah kita telah memetakan siapasiapa saja terlibat dalam penyusunan omnibus law dan siapa saja pihak yang berkonflik dalam proses penyusunan rancangan undang-undang omnibus law melalui konsep pemetaan konflik oleh Simon Fisher. Maka pada pembahasan ini kita akan mengkaji apa saja yang menjadi pilar pendukung hingga terjadinya konflik dalam proses penyusunan rancangan undang-undang tersebut, dengan menggunakan konsep Anologi Pilar Simon Fisher.

Dari hasil analisis penulis yang menggunakan alat bantu analogi pilar Simon Fisher maka ada beberapa pilar pendukung terjadinya konflik dalam proses penyusunan rancangan undang-undang omnibus law seperti kurangnya komunikasi politik, minimnya partisipasi politik dan adanya politik relation atau relasi politik yang di bangun oleh pemerintah dan pengusaha.

Berikut penjelasan secara rinci terkait 3 poin tersebut:

1. Kurangnya Komunikasi Politik

Pilar pertama yang menjadi penyangga dalam konflik tersebut adalah kurangnya komunikasi politik yang di bangun oleh pemerintah dan satgas kepada masyarakat sipil. Sehingga masyarakat sipil kesusahan dalam mendapatkan informasi perkembangan serta isi dari rancangan undang-undang omnibus law, seperti yang di jelaskan oleh Ketua Umum Konfederasi Kongres Aliansi Buruh Indonesia (Kasbi) Nining Elitos menilai pembahasan Omnibus Law Rancangan UndangUndang (RUU) Cipta Kerja, termasuk minim akses untuk mengetahui perkembangan mengenai pembahasan RUU tersebut. (nasional.kompas.com, 2020 April 30).

Padahal jika merujuk pada Undang-Undang No 14 Tahun 2008 tentang Keterbukaan Informasi telah di jelaskan bahwa hak memperoleh informasi merupakan hak asasi manusia dan keterbukaan informasi publik merupakan salah satu ciri penting negara demokratis yang menjunjung tinggi kedaulatan rakyat untuk mewujudkan penyelenggaraan negara yang baik. 


\begin{tabular}{|c|c|c|c|c|}
\hline JURNAL & \multirow{2}{*}{ NOLUME 2 } & \multirow{2}{*}{ HALAMAN 74-85 } & $\begin{array}{l}\text { ISSN 2655-8823 }(p) \\
\text { ISSN 2656-1786 }(e)\end{array}$ \\
\hline KOLABORASI RESOLUSI KONFLIK & VOLUME \\
\hline
\end{tabular}

Lebih lanjut pada Pasal 3 ayat 1 undang-undang ini menjelaskan tujuan dari keberadaan undangundang tersebut yaitu menjamin hak warga negara untuk mengetahui rencana pembuatan kebijakan publik, program kebijakan publik, dan proses pengambilan keputusan publik, serta alasan pengambilan suatu keputusan publik.

Maka dalam penerapan UU keterbukaan Informasi Publik melekat pada dua pihak yaitu penyelenggara pemerintahan dan masyarakat atau publik. Dalam Penyelenggara pemerintahan maka wajib menyediakan informasi publik kepada masyarakat, dalam implementasi publik maka seluruh kegiatan pemerintahan baik kebijakan publik, alasan mengambil kebijakan publik, pelayanan publik serta penyusunan anggaran pemerintahan harus terbuka dan mudah diakses oleh masyarakat. (Febriananingsih, 2012).

Sejalan dengan pandangan di atas (Setiaman, Sugiana, \& Mahameruaji, 2013) juga menjelaskan bahwa Pemerintah harus menyediakan informasi dengan berbagai infrastruktur yang di miliki agar masyarakat dengan mudah memberikan kontribusi atau partisipasi positif dalam penyelengaraan pemerintahan termaksud dalam pengambilan kebijakan.

Sehingga hadirnya UndangUndang Keterbukaan Informasi memiliki dampak yang baik dalam kehidupan sosial masyarakat dan politik. Melalui UU tersebut masyarakat mendapatkan informasi dengan mudah sehingga UU tersebut mampu membentuk masyarakat informasi yang transparan, efektif, efisien dan akuntabel. (Rifai, 2008).

Sebagai langkah dalam mewujudkan pemerintahan yang baik (Good Governance) harus memiliki informasi yang transparan, efektif dan akuntabel agar masyarakat secara langsung dapat terlibat dalam melakukan kontrol terhadap negara dalam segala aktifitas politiknya. (Retnowati, 2012).

Dari penjelasan di atas maka masyarakat seharusnya dengan mudah mendapatkan informasi publik dari rancangan undangundang omnibus law. Sebab hal tersebut menjadi mandat dari Undang-Undang Keterbukaan Informasi Publik.

Keterbukaan informasi publik menjadi salah satu langkah komunikasi politik yang seharusnya dilakukan oleh pemerintah dan satgas dalam memperkenalkan rancangan Undang-Undang omnibus law serta proses dalam pembuatannya. Menurut Bill Kovach dan Tom Rosenthiel, (dalam Susanto, 2013) " hak atas informasi merupakan hak dasar yang melekat pada manusia, atau sebagai kesadaran manusia untuk mengetahui hal hal diluar dirinya".

2. Politik Relation

Dari data yang sudah di jelaskan sebelumnya bahwa dalam proses penyusunan rancangan undang-undang omnibus law hanya melibatkan pihak-pihak pengusaha yang memiliki hubungan yang dekat dengan pemerintahan hingga membangun satu aliansi satuan gugus tugas. Dalam sistem pemerintahan yang demokratis hal ini menjadi salah satu bentuk kekerasan struktural terhadap masyarakat. 


\begin{tabular}{|c|c|c|c|c|}
\hline JURNAL & \multirow{2}{*}{ VOLUME 2 } & NOMOR 2 & HALAMAN 74-85 & $\begin{array}{l}\text { ISSN 2655-8823 }(p) \\
\text { ISSN 2656-1786 }(e)\end{array}$ \\
\hline
\end{tabular}

Dalam konsep kekerasan struktural Galtung (dalam Susan, 2009) tentang kekuasan struktural menjelasakan salah satu bentuk penggunaan kekuasan struktural yang di miliki oleh orang yang mempunyai wewenang untuk menciptakan kebijakan publik.

Sehingga kebijakan yang di miliki oleh pemerintah di gunakan untuk mendorong kepentingan mereka dalam membentuk satu aliansi dengan pihak pengusaha dengan membentuk Satgas bersama pemerintah dan kadin untuk konsultasi publik omnibus law. Claus Offe (dalam Angger, 2003) melakukan diskusi tentang krisis hubungan negara dan masyarakat dalam istilah kapitalisme yang tak terorganisir bersama Hilferding salah satu orang yang memberikan satu dasar ekonomi penting bagi Mazhab Frankfut dengan istilah Kapitalisme terorganisir. Dalam diskusinya mereka menjelaskan "bahwa kapitalisme memerlukan intervensi negara untuk membentengi dan mencegah kecendrungan krisis struktral".

Maka dalam proses penyusunan rancangan Undang-Undang omnibus law dengan membentuk satuan tugas yang di dominasi oleh pihak pengusaha adalah salah satu bentuk politk relation atau hubungan politik dari ke dua lembaga tersebut melalui kebijakan yang di miliki oleh pemerintah. Sehingga minimnya partisipasi politik bagi masyarakat kelas bawah yang tergabung dalam berbagai aliansi gerakan masyarakat sipil.

3. Minimnya Partisipasi Politik

Poin terakhir yang menjadi pilar penyangga adalah minimnya partisipasi politik. Dalam proses penyusunan rancangan UndangUndang omnibus law sangat minim partisipatif sebab tidak melibatkan masyarakat kelas bawah yang langsung merasakan dampak dari rancangan undang-undang tersebut. Dalam UU No 14 Tahun 2008 Tentang Keterbukaan Informasi Publik keterlibatan masyarakat dalam pengambilan kebijakan sangat di butuhkan dalam mewujudkan penyelenggaran negara yang baik.

Selanjutnya dalam UU No 12 Tahun 2011 Tentang Pembentukan Peraturan Perundang-Undangan Pasal 96 ayat 1 menjelaskan bahwa masyarakat berhak memberikan masukan secara lisan dan/atau tertulis dalam Pembentukan Peraturan Perundang-undangan.

Dalam tulisannya (Lubis, 2013) mebagi partisipasi atas dua yaitu partisipasi langsung dan partisipasi tidak langsung. Dua cara ini di gunakan untuk menggalang partisipasi masyarakat dalam pengambilan kebijakan partisipasi langsung di gunakan dengan cara tahap-tahap mediasi atau pertemuan secara langsung untuk melibatkan diri dalam penyusunan kebijakan sedangkan partisipasi tidak langsung menggunakan media sebagai alat untuk melibatkan diri dalam pembuatan kebijakan publik.

Maka kebijakan publik yang matang serta di terimah oleh masyarakat adalah kebijakan publik yang partisipatif melibatkan masyarakat secara langsung di dalamnya. (Damanik, Santosa, \& Nugroho, 2015). Dalam melibatkan partisipasi publik sebaiknya tidak melihat perbedaan jenis kelamin sebab masyarakat tanpa terkecuali memiliki hak dalam penentuan kebijakan pemerintahan dengan demikian keinginan dan harapan masyarakat dapat terakomodir. 


\begin{tabular}{|c|c|c|c|c|}
\hline JURNAL & \multirow{2}{*}{ VOLUME 2 } & NOMOR 2 & HALAMAN 74-85 & $\begin{array}{l}\text { ISSN 2655-8823 }(p) \\
\text { ISSN 2656-1786 }(e)\end{array}$ \\
\hline
\end{tabular}

Sanit (dalam Hasbi Wahyudi et al., 2013).

Jika kita merujuk pada data yang ada bahwa partisipasi politik masyarakat kelas bawah sangat kecil dalam proses penyusunan rancangan undang-undang omnibus law. Padahal masyarakat memiliki hak dalam rangka keterlibatan penyusunan kebijakan publik seperti yang sudah dimandatkan dalam undang-undang.

\section{KESIMPULAN}

Konflik yang terjadi dalam proses penyusuna rancangan undang-undang omnibus law antara pemerintah dan kelompok gerakan masyarakat sipil akibat dari kurangnya komunikasi politik, adanya politik relation dan minimnya Partisipasi politik. Hal tersebut mengakibatkan lahirnya produk undang-undang yang tidak demokratis, serta memiliki potensi untuk mendorong kepentingan segelintir kelompok. Sehingga hal tersebut akan menghasilkan konflik-konflik berkepanjangan.

Maka dalam setiap pengambilan kebijakan, pemerintah harus menjalankan mandat dari UU No 14 Tahun 2008 tentang keterbukaan Informasi, UU No 12 Tahun 2011 Tentang Peraturan PerundangUndangan sehingga masyarakat memiliki keterlibatan dalam pengambilan kebijakan hal ini akan meminimalisir terjadinya berbagai konflik yang berkaitan dengan kebijakan maupun proses penyusunan kebijakan.

\section{DAFTAR PUSTAKA}

Angger, B. (2003). TEORI SOSIAL KRITIS Kritik, Penerapan dan Implikasinya (Hadi Purwanto, ed.). Yogyakarta: Kreasi Wacana.

Martono, N. (2014). SOSIOLOGI PERUBAHAN SOSIAL Prespektif Klasik, Modern, Posmodern, dan Poskolonial. Jakarta: Rajawali Pers.

Simon Fisher, Dekha Ibrahim Abdi, Jawed Ludin, Richard Smith, Steve Williams,
S. W. (2001). MENGELOLA KONFLIK KETERAMPILAN DAN STRATEGI UNTUK BERTINDAK. Jakarta: The British Council, Indonesia.

Susan, N. (2009). Pengantar Sosiologi Konflik. Jakarta: Penanda Media Grup.

Undang-Undang Dasar 1945

Undang-Undang No 14 Tahun 2008. Tentang Keterbukaan Informasi Publik Undang-Undang No 12 Tahun 2011. Tentang Pembentukan Peraturan Perundang-Undangan.

\section{Bacaan Lain Jurnal dan Web}

Ady, T.D.A. (2020). Dua Lembaga Ini Kesulitan Akses Naskah RUU Cipta Lapangan Kerja. https://www.hukumonline.com/berita/b aca/lt5e33ddd1059a5/dua-lembaga-inikesulitan-akses-naskah-ruu-ciptalapangan

Andi, S. (2020). Ramai-ramai Menolak Omnibus Law RUU Cilaka, FRI: Berwatak Kolonial!.

https://news.detik.com/berita/d4878945/ramai-ramai-menolakomnibus-law-ruu-cilaka-fri-berwatakkolonial/3

Agil, S.H. (2020). Terkait Omnibus Law, Jokowi Bekerja Cepat atau Tergesagesa?

https://www.kompasiana.com/agilshab ib/5e49fd65d541df289f2c6f14/terkaitomnibus-law-jokowi-bekerja-cepatatau-tergesa-gesa?page $=1$

Alexander, H. (2020). Mengapa Mahasiswa Demo di DPR, Pasal Kontroversi RKUHP Jadi Alasan. https://tirto.id/mengapa-mahasiswademo-di-dpr-pasal-kontroversi-rkuhpjadi-alasan-eiHT

Andrian, $P$ (2020). Komposisi 'Bermasalah' Satgas Omnibus Law. https://tirto.id/komposisi-bermasalahsatgas-omnibus-law-enEn

Cnn indonesia. (2020). Puluhan Ribu Buruh Disebut Demo Tolak Omnibus Law via Medsos. https://www.cnnindonesia.com/nasiona 


\begin{tabular}{|c|c|c|c|c|}
\hline JURNAL & \multirow{2}{*}{ VOLUME 2 } & \multirow{2}{*}{ NOMOR 2 } & HALAMAN 74-85 & $\begin{array}{l}\text { ISSN 2655-8823 }(p) \\
\text { ISSN 2656-1786 }(e)\end{array}$ \\
\hline
\end{tabular}

1/20200409044223-32-

491881/puluhan-ribu-buruh-disebutdemo-tolak-omnibus-law-via-medsos

Damanik, M. P., Santosa, P. I., \& Nugroho, H. A. (2015). KERANGKA IMPLEMENTASI LAYANAN ECONSULTATION. (Snik), 163-168.

Dewan Perwakilan Rakyat Indonesia. (2020). Tugas dan Wewenang. http://www.dpr.go.id/tentang/tugaswewenang

Febriananingsih, N. (2012). Jurnal Rechts BPIRechts Jur. 1(April), 135-156.

Hasbi Wahyudi, Tantio Fernando, Azhari Ahmad, Ayu Khairani, Fatimah, Ivan Muhammad Agung, \& Mirra Noor Milla. (2013). Peran Kepercayaan politik dan Kepuasan Demokrasi terhadap Partisipasi Politik Mahasiswa. Jurnal Psikologi UIN Sultan Syarif Kasim Riau, 9(Desember), 94-99.

Hidayat, A., \& Arifin, Z. (2019). Politik Hukum Legislasi Sebagai SocioEquilibrium Di Indonesia. Jurnal Ius Constituendum, 4(2), 133. https://doi.org/10.26623/jic.v4i2.1654

Lubis, S. (2013). Partisipasi Masyarakat dalam Perumusan Kebijakan Publik. Politik Praktik, 1, 72-81.

Retnowati, E. (2012). Keterbukaan Informasi Publik Dan Good Governance (Antara Das Sein Dan Das Sollen). Perspektif, 17(1), 54. https://doi.org/10.30742/perspektif.v17 i1.94

Rifai, A. (2008). KEMERDEKAAN INFORMASI : Catatan atas UndangUndang Keterbukaan Informasi Publik. Jurnal Dakwah, 9(2), 101-116.

Setiaman, A., Sugiana, D., \& Mahameruaji, J. N. (2013). Implementasi Kebijakan Keterbukaan Informasi Publik. Jurnal Kajian Komunikasi, 1(2), 196-205. https://doi.org/10.24198/jkk.vol1n2.9

Simon Fisher, Dekha Ibrahim Abdi, Jawed Ludin, Richard Smith, Steve Williams, S. W. (2001). MENGELOLA KONFLIK KETERAMPILAN DAN STRATEGI UNTUK BERTINDAK.
Jakarta: The British Council, Indonesia.

Susanto, E. H. (2013). Dinamika Komunikasi Politik Dalam Pemilihan Umum. Jurnal Kajian Komunikasi, 1(2), 163-172. https://doi.org/10.24198/jkk.vol1n2.6

Zuldin, M. (2019). Ketimpangan Sebagai Penyebab Konflik. Temali: Jurnal Pembangunan Sosial, 2(1), 157-183. Retrieved from journal.uinsgd.ac.id > index.php > temali > article > download

Ihsanuddin. (2020). Mengenal Omnibus Law, Aturan "Sapu Jagat" yang Ditolak Buruh. https://nasional.kompas.com/read/2020 /01/20/13152061/mengenal-omnibus-

law-aturan-sapu-jagat-yang-ditolakburuh?page $=3$

Nicha, M. (2020). Akhirnya Draf RUU Omnibus Law Cipta Kerja Diserahkan ke DPR.

https://kumparan.com/kumparanbisnis/ akhirnya-draf-ruu-omnibus-law-ciptakerja-diserahkan-ke-dpr1spGYvTxtZx/full

Retnowati, E. (2012). Keterbukaan Informasi Publik Dan Good Governance (Antara Das Sein dan Das Sollen). Perspektif, 17(1), 54. https://doi.org/10.30742/perspektif.v17 i1.94

Rifai, A. (2008). KEMERDEKAAN INFORMASI : Catatan atas UndangUndang Keterbukaan Informasi Publik. Jurnal Dakwah, 9(2), 101-116.

Sania, M. (2020). Kasbi: Kaum Buruh Sulit Dapat Akses Terkait Pembahasan RUU Cipta Kerja. https://nasional.kompas.com/read/2020 /04/09/21443511/kasbi-kaum-buruhsulit-dapat-akses-terkait-pembahasanruu-cipta-kerja.

Setiaman, A., Sugiana, D., \& Mahameruaji, J. N. (2013). Implementasi Kebijakan Keterbukaan Informasi Publik. Jurnal Kajian Komunikasi, 1(2), 196-205. https://doi.org/10.24198/jkk.vol1n2.9 


\begin{tabular}{|c|c|c|c|c|}
\hline $\begin{array}{c}\text { JURNAL } \\
\text { KOLABORASI RESOLUSI KONFLIK }\end{array}$ & VOLUME 2 & NOMOR 2 & HALAMAN 74-85 & $\begin{array}{l}\text { ISSN 2655-8823 }(p) \\
\text { ISSN 2656-1786 }(e)\end{array}$ \\
\hline
\end{tabular}

Thohirin. (2020). Golkar dan Nasdem Satu

Suara Dukung Pengesahan Omnibus

Law.

https://www.cnnindonesia.com/nasional/2

0200309163409-32-481820/golkar-

dan-nasdem-satu-suara-dukung-

pengesahan-omnibus-law

Yosef, L.P. (2020). PSHK FH UII Desak

DPR RI Kembalikan RUU Omnibus

Law Cipta Kerja ke Presiden.

https://jogja.tribunnews.com/2020/03/1

1/pshk-fh-uii-desak-dpr-ri-kembalikanruu-omnibus-law-cipta-kerja-ke-

presiden.

Zuldin, M. (2019). Ketimpangan Sebagai

Penyebab Konflik. Temali: Jurnal

Pembangunan Sosial, 2(1), 157-183.

Retrieved from journal.uinsgd.ac.id >

index.php > temali > article > download. 